University of Texas Rio Grande Valley

ScholarWorks @ UTRGV

$12-2019$

\title{
Terrestrial snail communities of the lower rio grande valley are affected by human disturbance and correlate with vegetation community composition
}

Briante S. Lewis Najev

Alison Schofield

Raziel I. Flores

Benjamin T. Hutchins

J. Andrew McDonald

See next page for additional authors

Follow this and additional works at: https://scholarworks.utrgv.edu/bio_fac

Part of the Biology Commons

\section{Recommended Citation}

Lewis Najev, B. S., Schofield, A., Flores, R. I., Hutchins, B. T., Andrew McDonald, J., \& Perez, K. E. (2019). Terrestrial Snail Communities of the Lower Rio Grande Valley Are Affected by Human Disturbance and Correlate with Vegetation Community Composition. Southwestern Naturalist, 64(3/4), 216-227. https://doi.org/10.1894/0038-4909-64.3-4.216

This Article is brought to you for free and open access by the College of Sciences at ScholarWorks @ UTRGV. It has been accepted for inclusion in Biology Faculty Publications and Presentations by an authorized administrator of ScholarWorks@ UTRGV. For more information, please contact justin.white@utrgv.edu,william.flores01@utrgv.edu. 


\section{Authors}

Briante S. Lewis Najev, Alison Schofield, Raziel I. Flores, Benjamin T. Hutchins, J. Andrew McDonald, and Kathryn E. Perez 


\title{
TERRESTRIAL SNAIL COMMUNITIES OF THE LOWER RIO GRANDE VALLEY ARE AFFECTED BY HUMAN DISTURBANCE AND CORRELATE WITH VEGETATION COMMUNITY COMPOSITION
}

\author{
Briante S. Lewis Najev, Alison Schofield, Raziel i. Flores, Benjamin T. Hutchins, J. Andrew McDonald, and \\ Kathrin E. Perez*
}

\author{
The University of Texas Rio Grande Valley, 1201 W University Drive, Edinburg, TX 78539 (BSLN, AS, RIF, JAM, KEP) \\ Edwards Aquifer Research E Data Center, Texas State University, Department of Biology, 601 University Drive, \\ San Marcos TX 78666 (BTH) \\ *Correspondent: perezke@gmail.com
}

\begin{abstract}
The lower Rio Grande Valley of Texas (LRGV) contains a unique, subtropical, semiarid floodplain with most of the few remaining Tamaulipan thorn forests in the United States. Less than $2 \%$ of Tamaulipan thorn forest remains, with urban and agricultural conversion potentially threatening diverse plant and animal communities native to the habitat. We performed vegetative community surveys and conducted a comprehensive survey of terrestrial snail communities in intact (refugia sites, minimally altered in recent times) and altered (previously cleared and regrown or restored) Tamaulipan thorn forest habitats of the LRGV. In a comparison of intact and altered sites that have comparable vegetation (paired sites), we found that intact sites had a less speciesrich snail community than their altered counterparts, but this difference was not statistically significant. This counterintuitive result, in part reflects the fact that the most species-rich, intact snail communities (i.e., Sabal Palm Forest) have no altered (restored or regrown) counterparts and so were not included in the paired comparisons. A nestedness analysis supports this, finding that these unique intact sites, which have the highest species richness and no comparable restored sites, contain the largest pool of species in South Texas. Species richness of snails significantly correlated with a precipitation gradient. A general linear model incorporating mean canopy cover, mean plant height, plant abundance, and plant species richness shows a significant correlation with snail communities. This study is the only comprehensive survey of the snail communities of the lower Rio Grande Valley.
\end{abstract}

Resumen-La cuenca baja del río Grande en Texas (LRGV) contiene una llanura de inundación única, subtropical y semiárida con la mayoría de los remanentes de los bosques espinosos tamaulipecos en los Estados Unidos. Queda menos del 2\% del bosque espinoso tamaulipeco, con la conversión a áreas urbanas y agrícolas potencialmente amenazando las comunidades diversas de plantas y animales nativos del hábitat. Hicimos muestreos de comunidades vegetales y un muestreo comprensivo de comunidades de caracoles terrestres en hábitats de bosques espinosos tamaulipecos intactos (sitios refugio, con poca alteración en tiempos recientes) y perturbados (previamente cortados y recuperados o restaurados) en el LRGV. En una comparación de los sitios intactos con los perturbados con la vegetación comparable (sitios emparejados), sitios intactos tuvieron comunidades con menos riqueza de especies de caracoles que sus contrapartes alteradas, aunque la diferencia no fue estadísticamente significativa. Este resultado contra intuitivo, en parte refleja el hecho de que las comunidades intactas de caracoles más ricas en especies (o sea, Sabal Palm Forest) no tienen contrapartes alteradas (restauradas o regeneradas) y por eso no fueron incluidas en las comparaciones emparejadas. Un análisis de anidamiento respalda esto, encontrando que estos únicos sitios intactos, que tienen la mayor riqueza de especies y ningún sitio comparable restaurado, contienen el grupo más grande de especies en el sur de Texas. La riqueza de especies de caracoles se correlacionó significativamente con un gradiente de precipitación. Un modelo lineal general incorporando el promedio de cobertura del dosel, el promedio de altura vegetal, la abundancia de plantas, y la riqueza de especies de plantas muestra una correlación significativa con comunidades de caracoles. Este es el único muestreo comprensivo de las comunidades de caracoles de la cuenca baja del río Grande.

Tamaulipan thorn forest is a broad term encompassing a number of native plant communities in South Texas, primarily in the lower Rio Grande Valley (LRGV), and northern Mexico (Blair, 1950). Researchers believe that unmodified thorn forest habitat, characterized by drought-resistant, thorny, and spiny plants such as honey mesquite (Prosopis glandulosa), ebony (Ebenopsis ebano), and prickly-pear cactus (Opuntia engelmannii var. lindhei- 
meri), occupy less than $2 \%$ of the former extent of this habitat in the LRGV (Jahrsdoerfer and Leslie, 1988). The World Wildlife Fund considers the last remaining Tamaulipan thorn forest in the LRGV of Texas to be critically threatened (Cook et al., 2000) because of threats by human alteration like agriculture and urbanization. As an example, Cameron County, in the eastern portion of the study area, lost $91 \%$ of its native vegetation between the mid-1930s and 1983 (Tremblay et al., 2005). Tamaulipan Palm Grove Riparian Forest, $\sim 16,200$ ha in the 19 th century, was only 1,418 ha by the late 20 th century (Jahrsdoerfer and Leslie, 1988; Lockett and Read, 1990).

Tamaulipan thorn forest includes several habitat types (Elliott et al., 2014; NatureServe, http://www.natureserve. $\mathrm{org} /$ ) determined by soil composition, distance from water, underlying geology, precipitation, and plant community composition. Western thorn forest sites (e.g., Tamaulipan calcareous thornscrub) are characterized by caliche substrates and dominant plant species such as guajillo acacia (Senegalia berlandieri) and blackbrush acacia (Vachellia rigidula; Leslie, 2016). The western sites are drier with an annual precipitation of $54.9 \mathrm{~cm}$ (Eddy and Judd, 2004) and generally occur at slightly higher elevations (C. R. Hathcock et al., unpubl. data, 2012). Eastern thorn forest habitats are wetter with an annual precipitation around $71.5 \mathrm{~cm}$ (Eddy and Judd, 2004). The eastern sites have lowland habitat types such as sabal palm (Sabal mexicana) forest, wind tidal flats, and middelta thorn forest (Jahrsdoerfer and Leslie, 1988).

Snail communities are affected by plant communities (Horsák et al., 2009b; Hoffmann et al., 2011; Dvořáková and Horsák, 2012) because vegetation composition can influence soil nitrogen and calcium concentration (Horsák et al., 2009a), resulting in distinct microclimates (Dvořáková and Horsák, 2012). Hoffmann et al. (2011) supports that snail and vegetation communities follow precipitation and temperature gradients. Plant communities may indirectly influence snail communities by regulating leaf litter composition, physical structure, and moisture (Getz and Uetz, 1994). Moisture of microhabitats is particularly important to snails because they are susceptible to desiccation (Abdel-Rehim, 1983; Rankevich et al., 1996; Staikou, 1999). These microclimates harbor fungal hyphae (Caldwell, 1993; Maraun et al., 2003) and decomposing leaf litter (Steensma et al., 2009) on which most snails feed (Richardson, 1975; Caldwell, 1993). Researchers have demonstrated that features such as leaf litter depth (Hotopp, 2002), deadwood (Müller et al., 2005), and coarse woody debris (Caldwell, 1993; Kappes et al., 2006) increase terrestrial snail species richness, density, biodiversity, and abundance.

Snail community diversity and abundance can be negatively affected by human-driven habitat alteration (Lososová et al., 2011) such as clear-cutting (Hylander et al., 2004), prescribed burning (Nekola, 2002; Severns,
2005), urban development (Baur and Baur, 1993; Lososová et al., 2011), and even recreational activities (McMillan et al., 2003). Disturbances can lead to extirpation of native species and facilitate invasion by introduced species (Lake and O'Dowd, 1991; Byers, 2002). In a study of old-growth and second-growth forests of the Appalachian Mountains in eastern North America, Douglas et al. (2013) found that snail community composition measures such as species richness, diversity, and relative abundances were affected by habitat alteration.

Faunal studies of Tamaulipan thorn forest have largely focused on vertebrates (Brush, 2005; Haines et al., 2006; Brush and Conway, 2016) and insects (Dirrigl, 2012; Vitek et al., 2014; Cortez et al., 2017), and researchers have not previously characterized the land snail community outside of opportunistic sampling focused primarily on largebodied land snails ( $>5 \mathrm{~mm}$ maximum shell dimension; Ideker, 1979). Most malacological studies in North America have focused on larger snails even though $44 \%$ of the United States snail fauna are microsnails less than 5 $\mathrm{mm}$ in maximum shell dimension (Nekola, 2014). This study is the only comprehensive survey of the snails of the lower Rio Grande Valley of Texas.

We compared snail community composition in native and anthropogenically altered habitats in a different region of the United States: the Tamaulipan thorn forest in Texas. We included most of the last remaining patches of minimally altered (intact) Tamaulipan thorn forest in the LRGV of Texas as well as paired, nonintact (altered) examples of the same habitats. We examined intact and altered sites specifically to address the following questions. (1) Is there a difference in snail community composition between intact habitats and altered habitats? (2) Do the vegetative communities of the Tamaulipan thorn forest influence land snail community composition? We hypothesize that habitat disturbance in the LRGV will negatively affect snail communities (Watters et al., 2005; Horsák et al., 2009 $a$; Douglas et al., 2013). Based on findings by Horsák et al. (2009b) and Hettenbergerová et al. (2013) we hypothesize that vegetation community composition will influence snail community composition, possibly indirectly.

Materials and Methods-Field-We sampled plant and snail community composition at pairs of intact $(n=8)$ and altered $(n$ $=5$ ) sites (Fig. 1). We chose intact sites based on literature review of the Rio Grande Valley and the expertise of the authors (J.A.M., R.I.F.), and United States Fish and Wildlife Service staff. Human activities have altered all Tamaulipan thorn forest habitats, but we sampled most of the remaining, minimally altered, refugial thorn forest patches in the Rio Grande Valley of Texas. Intact sites contain native plant species characterized by long-lived, woody perennials of climax vegetation. For comparison with intact sites, altered site counterparts represent restored or regrown examples of the same habitat type; we chose these sites based on geographic region and habitat characteristics defined by the Texas Ecosystem Analytical Mapper (Texas Parks 


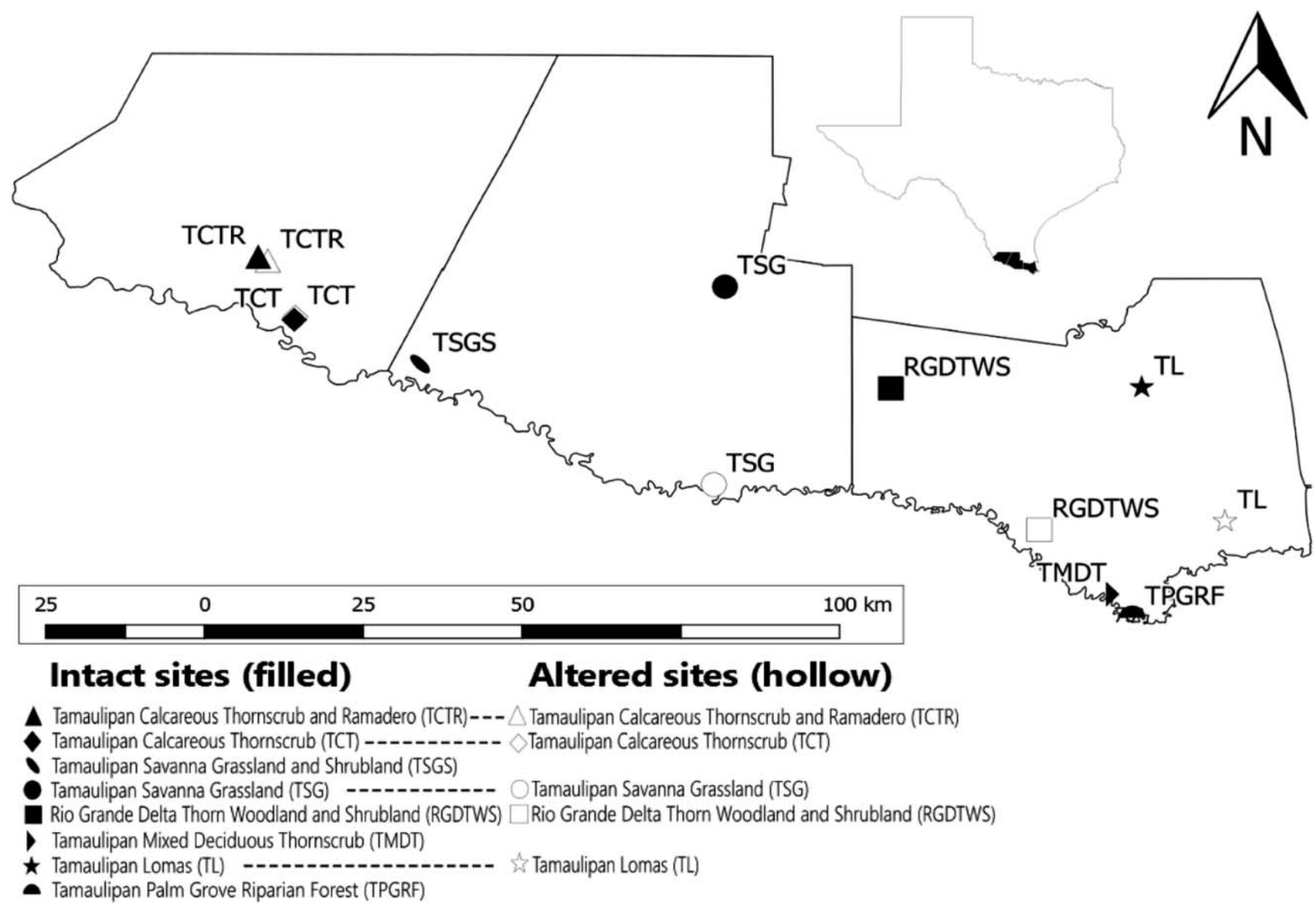

Fig. 1-The location of sites surveyed and their habitat types in the Lower Rio Grande Valley of Texas. The legend shows the abbreviations of habitat types and their symbols. The legend has pairs of altered and intact sites horizontally adjacent to each other; if there is no habitat type adjacent there is no paired site. The intact sites have a filled symbol and the altered sites have a hollow symbol; we follow this pattern throughout the article. The survey region in the reference map of Texas is in black.

and Wildlife Department, http://tpwd.texas.gov/gis/team/). Access was limited to public lands and one private ranch. All intact sites were closely associated with adjacent disturbed plant communities that have varying histories of regeneration and restoration; most modest modifications of intact sites happened before the 21 st century.

We were unable to sample altered counterparts for three intact habitats types: Tamaulipan palm grove riparian forest (TPGRF) at the Gorgas Foundation Sabal Palm Sanctuary, Tamaulipan savanna grassland and shrubland (TSGS) at the Lower Rio Grande Valley National Wildlife Refuge (NWR) Yturria Tract, and Tamaulipan mixed deciduous thorn forest (TMDT) at the La Posada Montezuma Cypress Preserve (City of Brownsville, Texas). These three habitat types are unrestored and so there are not altered examples available for comparison. We surveyed for snails in these intact sites with no altered counterparts, but some analyses only considered paired sites data.

We sampled plant community composition of woody vegetation $\geq 1 \mathrm{~m}$ in height within two $50-\times 20$-m transects. In these transects, we recorded species frequency, height, and canopy cover; R.I.F. (in litt.) provided additional detail on plant community sampling. We used a targeted, rather than random, sampling strategy for snails based on the findings of Cameron and Pokryszko (2005), which states that random sampling underestimates the land snail community compared with targeted sampling, which accounts for unevenly distributed moisture, soil texture, leaf litter, and coarse woody debris. Sampling included collecting large-bodied snails by hand, collecting leaf litter and the organic layer of soil, and shaking brush and moss over sieves. In the field, we passed soil and leaf litter through a $2.0-\mathrm{mm}$ mesh sieve followed by a $0.65-\mathrm{mm}$ mesh sieve. We attempted to standardize sampling effort across sites by continuing collection in the field until we observed about 200 microsnails on the $0.65-\mathrm{mm}$ sieve surface at each site. We recorded each sampling site location using a hand-held global positioning system (Garmin Montana 680t, Salem, Oregon) with an estimated error of $\pm 3.65 \mathrm{~m}$.

In the laboratory, we dried the remaining leaf litter at room temperature for 1-3 days, depending on the initial moisture level of the sample. We sieved leaf litter samples twice to remove additional soil before fully sorting the remaining leaf litter and soil under a dissecting microscope. A team of snail taxonomic experts-Jeffrey C. Nekola, K.E.P., and B.T.H.—identified shells to species (or the lowest taxonomic level possible based on shells). We have vouchered materials presented in this article at the Sam Houston State University Natural History Museum (SHSU accession numbers 2626-3847). 
Three introduced species were encountered in our study: Gulella (Huttonella) bicolor, Allopeas gracile, and Praticolella mexicana. Gulella (Huttonella) bicolor is a possibly native species of East Asia, Allopeas gracile is native to Latin America, and Praticolella mexicana is native to Mexico (Robinson, 1999). Although the native range of Praticolella mexicana is fairly close to the lower Rio Grande Valley importation of fruits and vegetables introduced it to the United States (Perez et al., 2017).

Statistical Analysis-Unless otherwise stated, we conducted statistical analyses in JMP Version 11 (SAS Institute Inc., Cary, North Carolina). We performed a pooled $t$ test on species richness of snail communities by disturbance type and regressed it against the precipitation gradient present in the region. We drew values for average monthly precipitation at each site from the WorldClim database extracted using Diva-GIS (Hijmans et al., 2001, 2005). We performed a standard least squares regression analysis on snail species richness at paired intact and altered sites and plant species richness at intact sites against precipitation.

To examine the influence of the plant community on the snail community at intact sites we produced a general linear model (GLM) using the normal (Gaussian) distribution and default link function: identity. This analysis included snail species richness as the response variable, with mean canopy cover, plant height, plant species richness, and plant abundance as explanatory variables. We also examined altered and intact sites with a GLM using snail species richness as the response and habitat type and disturbance type as explanatory variables. We conducted these analyses separately as no plant variable data exists for altered sites.

We used presence-absence data in the nestedness analysis. We calculated a nestedness metric (nodf) based on overlap (amount of species presence in a column and rows) and decreasing fill value (marginal totals between all pairs of columns and rows) using presence-absence snail community data in $\mathrm{R}$ ( $\mathrm{R}$ Core Team, 3.4.2, Vienna, Austria). We used the package "vegan" (Community Ecology Package R version 3.4.2) and the "nestednodf" function (Almeida-Neto et al., 2008) to calculate the nodf and nested fill value. We calculated temperature of the nestedness plot using "nestedtemp" to show if communities are subsets of other communities. We determined significance by using "oecosimu" and creating a null model using the function "commsim" with the arguments "tswap" and "curveball."

To further examine the influence the plant community has on the snail community we performed a principal component analysis on plant community data to assign plant species to one of four habitat-type categories based on clustering along the first principal component axis (Table 1). We used presence-absence data in a Bray-Curtis similarity matrix in R (R Core Team, 2013) to calculate the similarities among paired sites, using the argument "vegdist" (Van den Brink and Ter Braak, 1998). We performed nonmetric multidimensional scaling, using the BrayCurtis similarity matrix to examine relationships between snail communities and plant community characteristics of intact sites. We calculated this analysis using the "vegan" package of $\mathrm{R}$, the function "monoMDS" with 250 iterations and "hybrid" regressions and a stress of type 1 . We used the function "envfit" to investigate the influence of the environmental variables on the snail community composition and to add the correlation of plant groups on the nonmetric multidimensional scaling as a joint biplot.

Results-Mean snail species richness of intact sites (7.1 \pm 2.1 ) was lower than at altered sites $(9.4 \pm 1.8)$, but not significantly different ( $t$ test, $P=0.4652$; Fig. 2 ). The effect of precipitation on the snail species richness in intact sites was significant $\left(R^{2}=0.43, P=0.0162\right)$. Snail species richness for altered sites correlated with precipitation $\left(R^{2}=0.39\right)$ but was not significant $(P=0.5092)$. Plant communities did not follow a precipitation gradient $\left(R^{2}=0.02, P=0.8386\right)$.

The GLM of intact snail community species richness by plant community variables-mean canopy cover, mean plant height, plant abundance, and plant species richness-was significant (GLM, $\chi^{2}=17.1955, d f=4, P=$ 0.0018 ) and had a low overdispersion of 3.5092. The effect tests for individual variables were not significant (Table 2). Although these trends were not significant, snail species richness showed a positive relationship with mean canopy cover and mean plant height and no relationship with plant abundance and plant richness. A GLM of intact and altered snail community species richness by the environmental variables of habitat type and disturbance type was significant (GLM, $\chi^{2}=41.7248$, $d f=8, P<0.001)$ with a low overdispersion value of 1.0. Habitat type $(d f=7, P<0.001)$ and disturbance type $(d f$ $=1, P<0.001)$ were significant effects when examined individually (Table 3).

The nestedness analysis is a measure of whether the snail communities are independent or are subsets of each other (Fig. 3). The data shows that the LRGV snail communities are not significantly nested with a nodf value of 59.13, a nestedness fill of $30 \%$, and nested temperature of 15.29 (nodf $P=0.09$; temperature $P=$ 0.07). Praticolella trimatris, Praticolella salina, and Allopeas gracile do not follow the nestedness pattern of the other species (Fig. 3).

The most abundant species in paired intact sites was Gastrocopta pellucida (77.5\%), followed by Gastrocopta riparia (15.77\%) and Pupisoma dioscoricola (5.03\%; Table 4). Paired altered sites had a higher species richness compared with paired intact sites (Table 4) although the most species-rich sites were intact sites without altered counterparts (Fig. 3). In altered sites, G. pellucida $(35.74 \%)$ was the most abundant species followed by Hawaiia minuscula (23.38\%). Polygyra cereolus (0.02\%) and Praticolella trimatris $(0.02 \%)$, both macro-snails, were the least abundant species in intact and altered sites (Table 4). There were three introduced species in the paired sites: Allopeas gracile (3 in intact Tamaulipan Lomas), Praticolella mexicana (9 in altered Tamaulipan Savanna Grassland and Shrubland), and Gulella (Huttonella) bicolor (12 in intact Tamaulipan Mixed Deciduous Thornscrub and Tamaulipan Palm Grove Riparian Forest).

Table 5 shows the abundance and percentage of snail 
TABLE 1-Plant species groups based on the first ordination axis of a principal component analysis. The numbers with the plant groups are the range of values for the first principal component axis. $-=$ not applicable.

\begin{tabular}{|c|c|c|c|}
\hline $\begin{array}{c}\text { Riparian Montezuma } \\
\text { Cypress-Sabal Woodlands }\end{array}$ & $\begin{array}{c}\text { Rio Grande } \\
\text { Delta Thornforest }\end{array}$ & $\begin{array}{l}\text { Semiarid } \\
\text { Thornforest }\end{array}$ & $\begin{array}{c}\text { Arid } \\
\text { Upland Scrub }\end{array}$ \\
\hline $\begin{array}{c}\text { Group } 1 \\
(-4.53669 \text { to }-3.01312)\end{array}$ & $\begin{array}{c}\text { Group } 2 \\
(-2.87562 \text { to }-1.03962)\end{array}$ & $\begin{array}{c}\text { Group } 3 \\
(-0.74336 \text { to } 1.79934)\end{array}$ & $\begin{array}{c}\text { Group } 4 \\
(2.35997 \text { to } 4.01231)\end{array}$ \\
\hline Carica papaya & Abutilon hypoleucum & Aloysia gratissima & Aloysia macrostachya \\
\hline Celtis laevigata & Adelia vaseyi & Amyris madrensis & Citharexylum brachyanthum \\
\hline Cocculus diversifolius & Baccharis neglecta & Amyris texana & Cylindropuntia leptocaulis \\
\hline Ficus benjamina & Chiococca alba & Bastardia viscosa & Eysenhardtia texana \\
\hline Fraxinus berlandieriana & Chromolaena odorata & Bernardia myricifolia & Guaiacum angustifolium \\
\hline Leucaena pulverulenta & Condalia hookeri & Carlwrightia parvilora & Jatropha dioica \\
\hline Malpighia glabra & Diospyros texana & Castela ehrenbergiana & Jefea brevifolia \\
\hline Malvaviscus arboreus & Ebenopsis ebano & Celtis pallida & Karwinskia humboldtiana \\
\hline Nekemias arborea & Ehretia anacua & Citharexylum berlandieri & Leucophyllum frutescens \\
\hline Pisonia aculeata & Erythrina herbacea & Cordia boissieri & Lippia graveolens \\
\hline Sabal mexicana & Havardia pallens & Croton humilis & Lycium berlandieri \\
\hline Salix nigra & Petiveria alliacea & Croton incanus & Meximalva filipes \\
\hline Schinus terebinthifolius & Pluchea carolinensis & Ephedra antisiphylitica & Parthenium incanum \\
\hline Solanum erianthum & Ziziphus obtusifolia & Forestiera angustifolia & Schaefferia cuneifolia \\
\hline Solanum pseudocapsicum & - & Gochnatia hypoleuca & Senegalia berlandieri \\
\hline Taxodium mucronatum & - & Helietta parvifolia & Vachellia rigidula \\
\hline Triadiaca sebifera & - & Hibiscus martianus & Yucca treculeana \\
\hline Washingtonia robusta & - & Koeberlinia spinosa & - \\
\hline Xylosma flexuosa & - & Lantana achyranthifolia & - \\
\hline- & - & Lantana urticoides & - \\
\hline - & - & Opuntia engelmanni & - \\
\hline - & - & Parkinsonia aculeata & - \\
\hline - & - & Parkinsonia texana & - \\
\hline - & - & Phaulothamnus spinescens & - \\
\hline - & - & Prosopis glandulosa & - \\
\hline - & - & Randia rhagocarpa & - \\
\hline - & - & Salvia ballotiflora & - \\
\hline - & - & Sideroxylon celastrinum & - \\
\hline - & - & Tamaulipa azurea & - \\
\hline - & - & Trixis inula & - \\
\hline - & - & Vachellia farnesiana & - \\
\hline - & - & Vachellia schaffneri & - \\
\hline - & - & Viguiera stenoloba & - \\
\hline- & - & Zanthoxylon fagara & - \\
\hline \multicolumn{4}{|l|}{ Total no. of individuals } \\
\hline 419 & 848 & 5,329 & 3,465 \\
\hline
\end{tabular}

individuals and species in all intact sites. The most abundant snail species was Gastrocopta pellucida $(63.78 \%)$, followed by Gastrocopta riparia $(10.3 \%)$ and Pupisoma dioscoricola $(5.08 \%)$. The most common macrosnail species were Rabdotus alternatus (0.74\%) and Linisa texasiana $(0.29 \%)$. Helicina orbiculata $(0.02 \%)$ and Praticolella trimatris $(0.02 \%)$ were still the least abundant species in intact sites. We only found Praticolella trimatris twice.

We identified 84 plant species in plant community surveys. In the principal component analysis, principal component 1 accounted for $25.67 \%$ of variation in plant community composition. Plant species clustered into four groups on principal component 1: Riparian Montezuma Cypress-Sabal Woodlands (plant group 1; axis range =
-4.53 to -3.01 ), Rio Grande Delta Thornforest (plant group 2; axis range $=-2.87$ to -1.03 ), Semiarid Thornforest (plant group 3; axis range $=-0.74$ to 1.79), and Arid Upland Scrub (plant group 4; axis range $=2.35$ to 4.01$)$. Group 1 includes riparian habitats, associated with resacas (isolated oxbows) of the Rio Grande delta and floodplain, and groups 2-4 are more upland, drier habitats where plants experience considerable water stress during most of the year. The list of plants species in each group are in Table 1 . We removed mean plant height from this analysis because of positive autocorrelation with mean canopy cover.

Plant group 1, Riparian Montezuma Cypress-Sabal Woodland, most reflects TMDT; Montezuma bald-cypress 


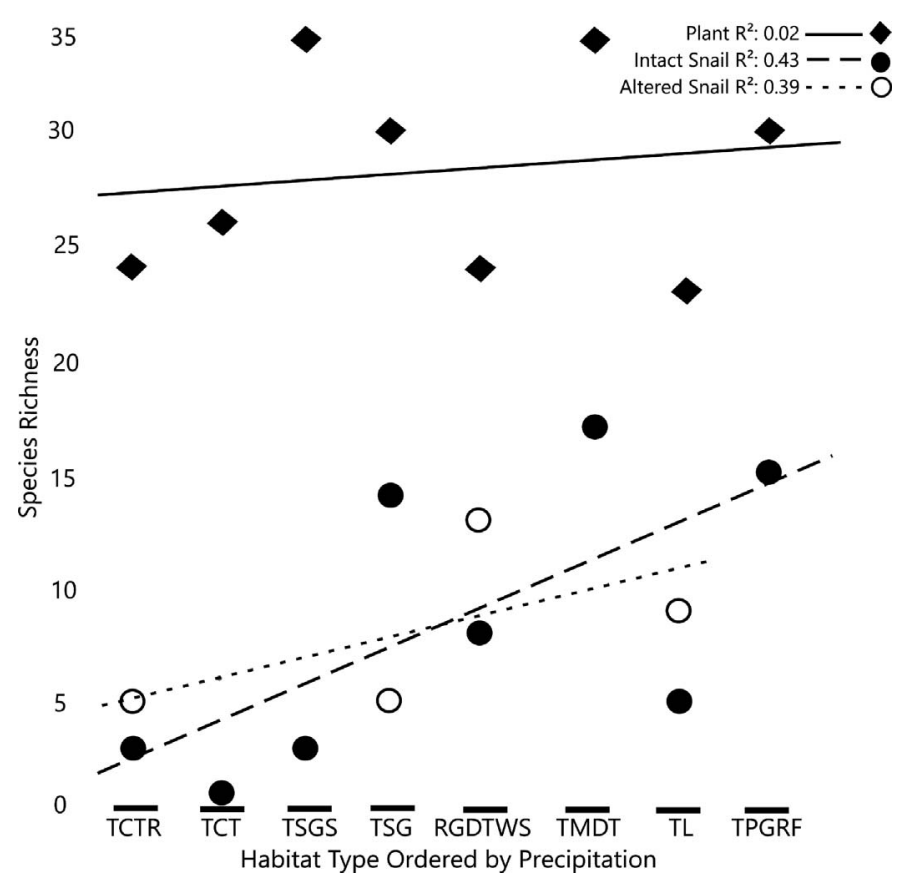

FIG. 2-Species richness for snail community differences in altered and intact sites and plant communities in intact sites. The $x$ axis is habitat type ordered by average monthly precipitation (ascending). $R^{2}$ values are on the top right corner. The solid line represents the correlation of plant species richness in intact sites. The dashed line (long dashes) represents the intact sites correlation. The dotted line (shorter dashes) represents the altered sites correlation. Hollow circles represent snail species richness in altered sites and filled dots represent snail species richness in intact sites. Diamonds represent plant communities. Snail species richness of intact sites significantly correlates with average monthly precipitation.

(Taxodium mucronatum) and sabal palm dominate it (Fig. $4)$. This vegetation has a closed canopy (ca. $8 \mathrm{~m}$ tall) and relatively dark understory, with emergent Montezuma cypress trees extending to $20 \mathrm{~m}$ tall. Plant group 2, Rio Grande Delta Thornforest, most reflects habitat type Rio Grande Delta Thorn Woodland and Shrubland (Fig. 4). This group is characterized by relatively high, closed canopies to $8 \mathrm{~m}$ tall with emergent palms, Havardia, and Ebenopsis trees reaching above $10 \mathrm{~m}$. Midstory trees and

TABLE 2-The effect tests of a normal (Gaussian) general linear model (GLM) of snail communities of intact sites with explanatory plant variables. The overall model was significant (GLM, $\chi^{2}=17.1955, d f=4, P=0.0018$ ); however, no single plant variables significantly influenced the snail communities at intact sites.

\begin{tabular}{lccc}
\hline \hline \multicolumn{1}{c}{ Term } & Estimate & $S E$ & $P$ \\
\hline Intercept & -5.860382 & 16.462032 & 0.7229 \\
Mean canopy cover & 3.4583568 & 5.2846405 & 0.5183 \\
Mean plant height & 3.5964839 & 1.9663701 & 0.0946 \\
Plant abundance & 0.0003856 & 0.0031467 & 0.9025 \\
Plant richness & -0.062273 & 0.4782282 & 0.8965 \\
\hline
\end{tabular}

TABLE 3-The effect tests of a normal (Gaussian) general linear model (GLM) of snail communities of intact and altered sites with the explanatory variables of: habitat and disturbance type was significant (GLM, $\chi^{2}=41.7248, d f=8, P<0.001$ ). Significant $P$ values indicated with an asterisk (*). RGDTWS $=$ Rio Grande delta thorn woodland and shrubland; TCT = Tamaulipan calcareous thornscrub; TCTR = Tamaulipan calcareous thornscrub and ramadero; $\mathrm{TL}=$ Tamaulipan lomas; TMDT $=$ Tamaulipan mixed deciduous thorn forest; TPGRF = Tamaulipan palm grove riparian forest; TSG = Tamaulipan savanna grassland.

\begin{tabular}{lccc}
\hline \multicolumn{1}{c}{ Term } & Estimate & \multicolumn{1}{c}{$S E$} & $P$ \\
\hline Intercept & 9.625 & 0.3162278 & $<0.0001^{*}$ \\
Disturbance type (altered) & 2.5 & 0.3162278 & $<0.0001^{*}$ \\
Habitat type (RGDTWS) & 0.875 & 0.6892024 & 0.2177 \\
Habitat type (TCT) & -6.125 & 0.6892024 & $<0.0001^{*}$ \\
Habitat type (TCTR) & -5.625 & 0.6892024 & $<0.0001^{*}$ \\
Habitat type (TL) & -2.625 & 0.6892024 & $0.0018^{*}$ \\
Habitat type (TMDT) & 9.875 & 0.9354143 & $<0.0001^{*}$ \\
Habitat type (TPGRF) & 7.875 & 0.9354143 & $<0.0001^{*}$ \\
Habitat type (TSG) & -0.125 & 0.6892024 & 0.8562 \\
\hline
\end{tabular}

lianas contribute to the stratification of this vegetation, under which deep leaf litter is conserved.

Plant group 3, Semiarid Thornforest, comprises short, thorny, deciduous forest with closed canopies from 3 to 5 $\mathrm{m}$ tall, with occasional emergent trees, such as Helietta parvifolia, Ebenopsis ebano, and Prosopis glandulosa (Fig. 4). The widespread associates of this plant group occur frequently and often as dominants at Lower Rio Grande Valley NWR Yturria Tract (Tamaulipan Savanna Grassland and Shrubland) and Laguna Atascosa National Wildlife Refuge (Tamulipan Lomas). Lower Rio Grande Valley NWR Yturria Tract (Tamaulipan Savanna Grassland and Shrubland) is the habitat type with the highest plant species richness. The plants in group 4, Arid Upland Scrub, have relatively short stature and exhibit broken or uneven canopies from 2 to $4 \mathrm{~m}$ tall, often with understories of short grasses. Plants of this group are often in calcareous soil and rocky or gravelly substrates, which are generally drier than regional loams. All plant species in this grouping grow at the Lower Rio Grande Valley NWR Los Olmos Tract (Tamaulipan Calcareous Thornscrub and Ramadero), and many are found at the Lower Rio Grande Valley NWR La Puerta Tract (Tamaulipan Calcareous Thornscrub), where calcareous soils also prevail.

The nonmetric multidimensional scaling had a type 1 stress of 0.07; maximum iterations are 250. Plant group 1 (Riparian Montezuma Cypress-Sabal Woodlands) is halfway in-between Tamaulipan Mixed Deciduous Thornscrub and Tamaulipan Palm Grove Riparian Forest. Plant group 2 (Rio Grande Delta Thornforest) is closest to Rio Grande Delta Thorn Woodland and Shrubland. Plant group 3 (Semiarid Thornforest) is closest to Tamaulipan Savanna Grassland and Shrubland, an eastern site. The 


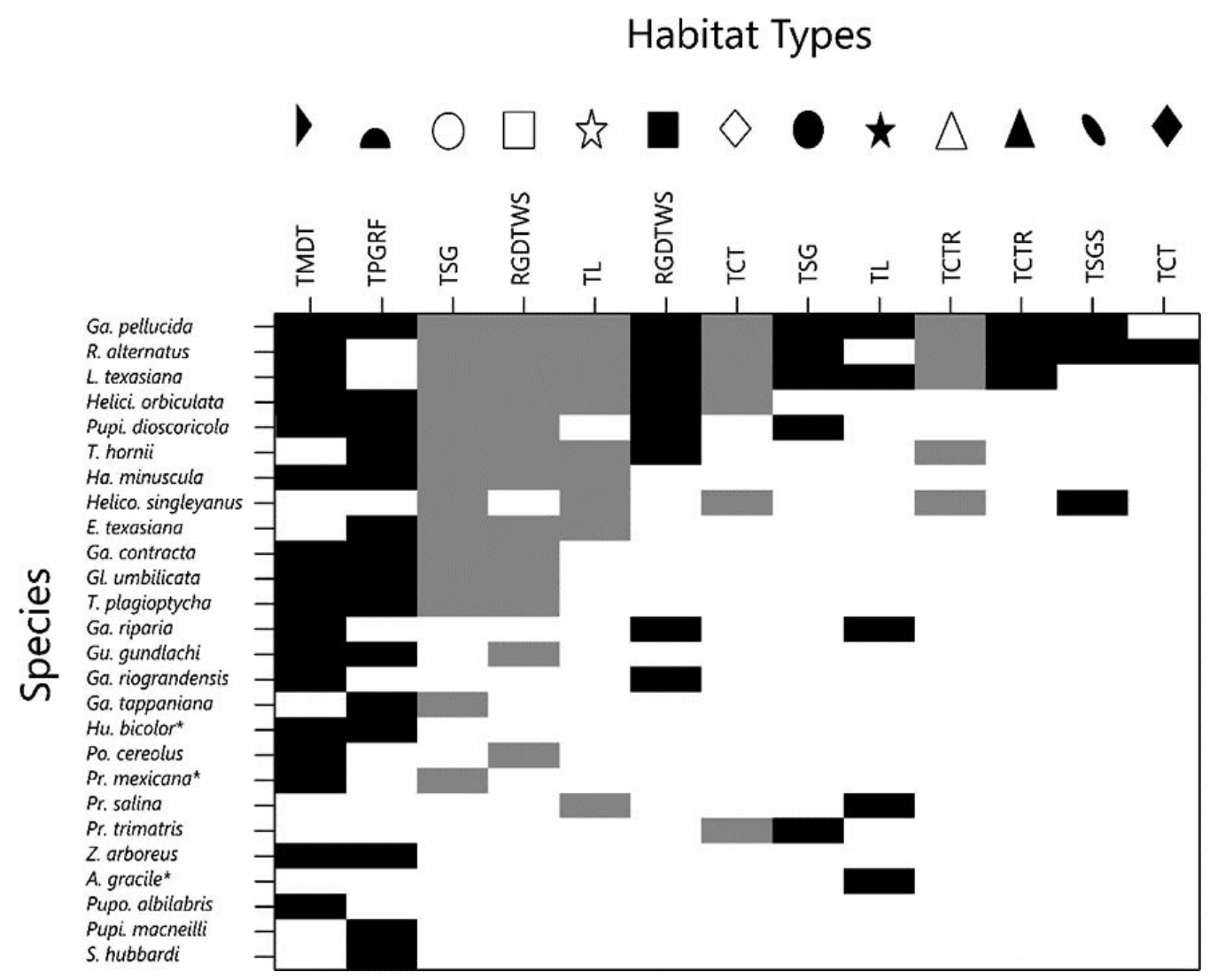

FIG. 3-Species presence across surveyed sites showing nestedness among snail communities. Filled and hollow symbols indicate intact and altered sites, respectively. Paired sites share the same symbol shape and symbology as Fig. 1. Black and gray fill indicate intact and altered sites, respectively. These communities are not significantly nested but note that the most species-rich sites are intact sites without an altered-site pair. TMDT = Tamaulipan mixed deciduous thornscrub; TPGRF = Tamaulipan palm grove riparian forest; TSG = Tamaulipan savanna grassland; RGDTWS = Rio Grande delta thorn woodland and shrubland; TL = Tamaulipan lomas; TCT $=$ Tamaulipan calcareous thornscrub; TCTR $=$ Tamaulipan calcareous thornscrub and ramadero; TSGS $=$ Tamaulipan savanna grassland and shrubland.

snail communities of Tamaulipan Calcareous Thornscrub and Ramadero and Tamaulipan Savanna Grassland and Shrubland and Tamaulipan Savanna Grassland and Tamaulipan Palm Grove Riparian Forest are least similar to each other, respectively. Plant group 4 (Arid Upland Scrub) is closest to Tamaulipan Calcareous Thornscrub and Ramadero (Fig. 4). Mean canopy cover is closest to Tamaulipan Calcareous Thornscrub.

Discussion-We examined the impacts of human disturbance and vegetative communities on snail communities in the LRGV of Texas. Surprisingly, we found average species richness was lower in intact than altered sites, but we attribute this to a lack of restoration in the riparian habitat types with the highest snail diversity. We found snail communities were positively correlated with precipitation and influenced by human disturbance and some aspects of vegetative community structure. The absence of Tamaulipan thorn forest that is unimpacted by humans, as well as restored riparian habitats, those that are the most species-rich, limit this study. We include only a single comparison site per habitat type, which may have made a difference in our findings if those sites were not representative of their habitat type.

Consequences of Human Disturbance on Snail Communities-While a comparison of simple species richness among paired intact and altered sites is not significant, when the entire snail community is examined, there are clear differences in the composition of snail communities across those sites (Tables 4 and 5). The nestedness analysis also reflects this, with intact sites supporting the largest species pool, and altered sites supporting a subset of those species (Fig. 3). One explanation for these results is that human disturbance has elevated or preserved species richness in these habitats; however, this could also be because of the lack of restoration of the most diverse sites, the riparian forests Tamaulipan Palm Grove Riparian Forest and Tamaulipan Mixed Deciduous Thornscrub.

Disturbance may have caused snail communities of altered sites to have a higher species richness than intact sites. There are examples of snail species richness increasing or having no effect from disturbance. In Poland, Cepaea nemoralis colonies benefit from distur- 
TABLE 4-A comparison of the abundances for snail species found across all paired intact and altered sites. Intact sites have fewer species compared with the altered sites. These values are ordered from the highest to lowest percentage of total individuals. Introduced species are indicated by an asterisk (*). Species found in only altered or only intact sites (within all paired sites) are indicated with a plus symbol $(+) .-=$ not applicable.

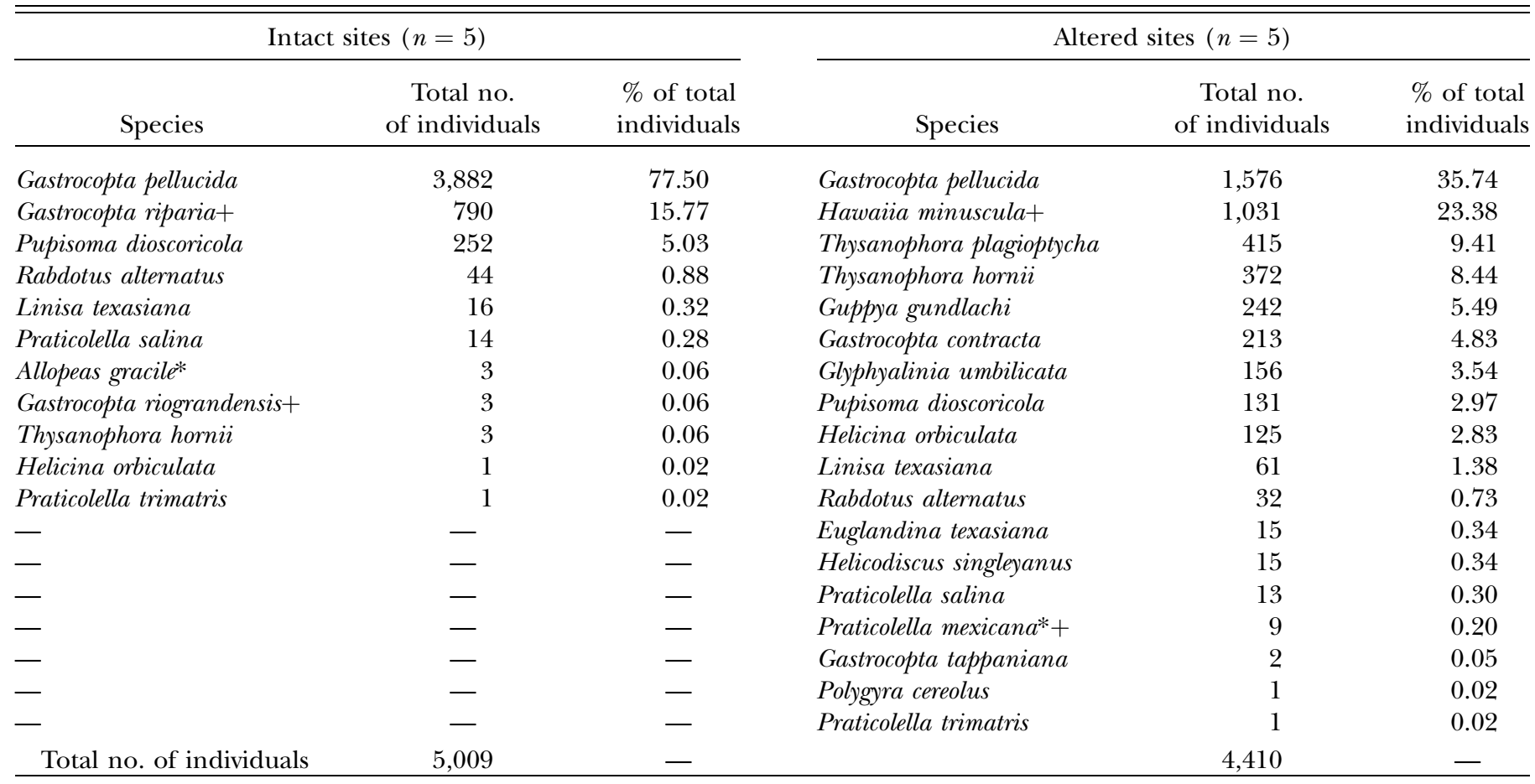

bance. Rosin et al. (2017) and Danielsen et al. (2009) failed to find an affect from anthropogenic disturbance on invertebrate species richness, and some altered sites had higher species richness than unaltered sites. The results could be explained by the Intermediate Disturbance Hypothesis (Roxburgh et al., 2004), but we do not have Tamaulipan thorn forest that is free from human influence for comparison as all remaining patches are at least somewhat disturbed by humans, even if they were never clear-cut. Disturbance may have caused increased heterogeneity of snail communities in altered sites, resulting in a higher species richness (Luniak, 2008). Alternatively, none of the "intact" sites were completely free of anthropogenic influence, as they are all relatively small tracts likely with significant edge effects.

A likely explanation for why we observed more snail species in altered sites compared with their intact counterparts is that the habitat types of the intact sites with the highest species richness have not been replanted or reforested and therefore do not have counterparts that we could examine. The TPGRF includes the last remaining uncleared sabal palms, located in the Gorgas Foundation Sabal Palm Sanctuary (Clover, 1937; Lockett and Read, 1990). This site has high snail and plant species richness and is distinct compared with other riparian sites in the LRGV (Lonard and Judd, 2002). TMDT is the La Posada Montezuma Cypress Preserve, one of the last places in the Rio Grande Valley with Montezuma baldcypresses (Taxodium mucronatum) (Suzán-Azpiri et al.,
2007). The Montezuma bald-cypress and sabal palms previously inhabited many riparian areas in the LRGV (Brush, 2005), but are now nearly completely extirpated (Bartlett, 1856; Lockett and Read, 1990; SFA Gardens, 2002). The Yturria tract of the Lower Rio Grande Valley NWR had the highest plant species richness and many cactus species; cacti take a long time to become established (Shreve, 1910; Mandujano et al., 2002; Peters et al., 2008). No altered counterparts to the three vegetation types mentioned above exist and we could not include any in statistical comparisons of intact vs. altered sites.

Precipitation Gradient Effects on Snail Community-Snail communities in the LRGV show a positive response to the precipitation gradient (Fig. 2), with higher species richness in eastern, riparian sites having a higher average annual rainfall $(54.9 \mathrm{~cm})$ compared with the less speciesrich western, drier sites $(16 \mathrm{~cm})$ (Eddy and Judd, 2004). Nearly all snail species found in the Rio Grande Valley are at the wettest, most diverse sites, and the other, more xeric, sites harbor subsets of the community. Researchers have found similar patterns of nestedness in other terrestrial invertebrate communities along an environmental gradient (Heino et al., 2010) and in snail communities (Hausdorf and Hennig, 2003; Hylander et al., 2004; Kappes et al., 2009; Hausdorf, 2018).

Vegetation Community Influence on Snail CommunityPlant community composition and structure influences the snail communities of the LRGV (Table 2; Fig. 4). 
TABLE 5-Snail species found in all sites along with the number of individuals and percentage of individuals, with values organized from the highest to lowest percentage of total individuals. Introduced species are indicated with an asterisk (*). Species found in only altered or only intact sites (within all sites) are indicated with a plus symbol $(+) . \quad$ - = not applicable.

\begin{tabular}{|c|c|c|c|c|c|}
\hline \multicolumn{3}{|c|}{ Intact sites $(n=8)$} & \multicolumn{3}{|c|}{ Altered sites $(n=5)$} \\
\hline Species & $\begin{array}{l}\text { Total no. } \\
\text { of individuals }\end{array}$ & $\begin{array}{l}\% \text { of total } \\
\text { individuals }\end{array}$ & Species & $\begin{array}{l}\text { Total no. } \\
\text { of individuals }\end{array}$ & $\begin{array}{l}\% \text { of total } \\
\text { individuals }\end{array}$ \\
\hline Gastrocopta pellucida & 4,905 & 63.78 & Gastrocopta pellucida & 1,576 & 35.74 \\
\hline Gastrocopta riparia+ & 792 & 10.30 & Hawaiia minuscula + & 1,031 & 23.38 \\
\hline Pupisoma dioscoricola & 391 & 5.08 & Thysanophora plagioptycha & 415 & 9.41 \\
\hline Helicina orbiculata & 208 & 2.70 & Gastrocopta contracta & 213 & 4.83 \\
\hline Guppya gundlachi & 194 & 2.52 & Glyphyalinia umbilicata & 156 & 3.54 \\
\hline Hawaiia minuscula & 191 & 2.48 & Pupisoma dioscoricola & 131 & 2.97 \\
\hline Glyphyalinia umbilicata & 146 & 1.90 & Helicina orbiculata & 125 & 2.83 \\
\hline Gastrocopta contracta & 88 & 1.14 & Linisa texasiana & 61 & 1.38 \\
\hline Huttonella (Gulella) bicolor*+ & 12 & 0.16 & Praticolella mexicana*+ & 9 & 0.20 \\
\hline Zonitoides arboreus + & 12 & 0.16 & Gastrocopta tappaniana & 2 & 0.05 \\
\hline Euglandina texasiana & 4 & 0.05 & Polygyra cereolus & 1 & 0.02 \\
\hline Gastrocopta riograndensis + & 4 & 0.05 & Praticolella trimatris & 1 & 0.02 \\
\hline Puposoma macneilli+ & 4 & 0.05 & - & - & - \\
\hline Allopeas gracile + & 3 & 0.04 & - & - & - \\
\hline Gastrocopta tappaniana & 3 & 0.04 & - & - & - \\
\hline Pupoides albilabris + & 3 & 0.04 & - & - & - \\
\hline Polygyra cereolus & 2 & 0.03 & - & - & - \\
\hline Praticolella mexicana* & 2 & 0.03 & - & - & - \\
\hline Helicodiscus singleyanus & 1 & 0.01 & - & - & - \\
\hline Praticolella trimatris & 1 & 0.01 & - & - & - \\
\hline
\end{tabular}

Specifically, the GLM analysis finds that mean canopy cover and mean plant height are correlated with increasing snail species richness. Evidence of the importance of canopy cover and plant height on snail communities exists; Zellweger et al. (2015) saw a positive effect of canopy cover on snail species richness. Snail species may even actively migrate to areas with more canopy cover (Davies, 2008). Lange (2003) also found a correlation between percentage of canopy cover and snail species richness (but see Emberton et al., 1997; Schilthuizen and Rutjes, 2001; Schilthuizen et al., 2005). Other studies have found significant positive correlations between plant abundance and snail abundance (Nilsson et al., 1988; Horáčková et al., 2014). However, we did not find studies focusing on plant height influencing snail community, which was a significant component of the GLM (Table 2).

In addition to influences of vegetation community characteristics on the snail community we also found significant effects of specific plant communities (Fig. 4). The snail communities at each site were associated with the plant communities present at that site. For example, plant group 4 (Arid Upland Scrub; Tamaulipan calcare- ous thornscrub and ramadero [TCTR] and Tamaulipan calcareous thornscrub [TCT]), is strongly associated with the snail community composition of TCTR, likely reflecting the presence of Praticollella trimatris and other species associated with dry, western habitats. In another example, plant group 1 (Riparian Montezuma CypressSabal Woodlands TPGRF and TMDT) is positioned between the snail communities from these two sites. We found the characteristic snails such as Gastrocopta riograndensis and Strobilops hubbardi, at those riparian sites. Riparian Montezuma Cypress-Sabal Woodlands historically had a large range in the LRGV of Texas. This includes stands dominated by sabal palms accounting for around $12 \%$ of the canopy cover of the LRGV of Texas (Lockett and Read, 1990) as well as extensive stands dominated by Montezuma bald-cypresses, which formerly occupied the banks of Rio Grande from Falcon Dam to Brownsville, Texas (George, 2008). Currently, this riparian habitat type, with the highest snail species richness, is restricted to single, isolated remaining habitats: Gorgas Foundation Sabal Palm Sanctuary (TPGRF) and La Posada Montezuma Cypress Preserve (TMDT). This leaves these now relictual and unique snail communities of the 
Maximum iterations: 250

Stress: 0.03

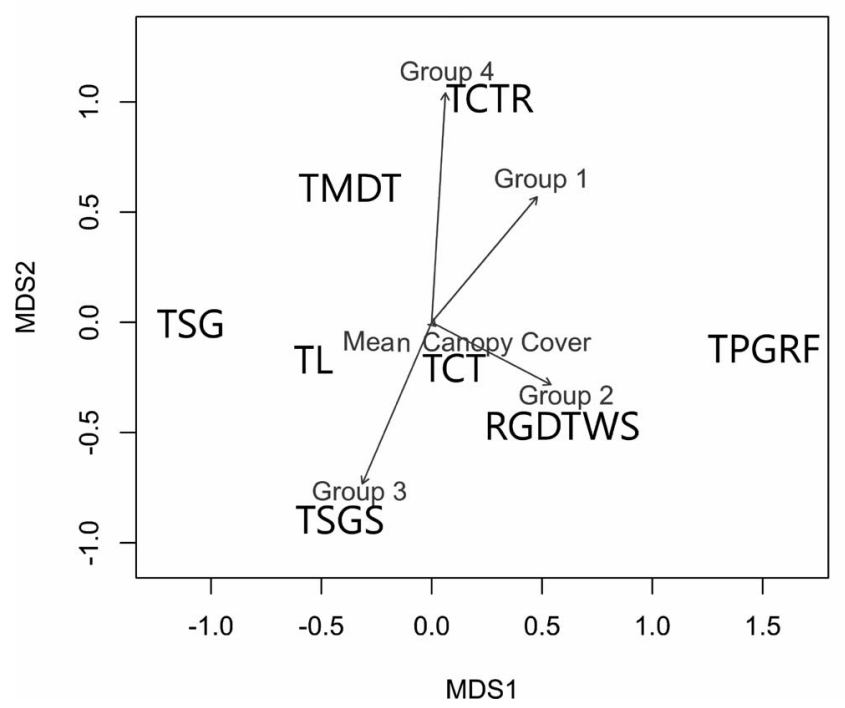

FIG. 4-A nonmetric multidimensional scaling plot that shows the nonparametric correlation of plant community groups and mean canopy to snail communities in all intact sites. It displays the distances of dissimilarity these snail communities have with the all habitat types. The abbreviations represent habitat types. The lines and words represent an overlay joint biplot of plant groups and mean canopy cover. Plant group 1 possibly correlates with Tamaulipan mixed deciduous thorn forest and Tamaulipan palm grove riparian forest. TCTR = Tamaulipan calcareous thornscrub and ramadero; TMDT $=$ Tamaulipan mixed diciduous thorn forest; TSG = Tamaulipan savanna grassland; TL = Tamaulipan lomas; TCT = Tamaulipan calcareous thornscrub; TPGRF = Tamaulipan palm grove riparian forest; RGDTWS = Rio Grande delta thorn woodland and shrubland; TSGS = Tamaulipan savanna grassland and shrubland.

LRGV in a threatened state as the LRGV continues to develop.

Conclusions-Our data suggest that altered sites harbor similar snail species to relatively intact sites in upland habitats, implying that altered, restored Tamaulipan thorn forest may support native land snails and perhaps other native invertebrate species. Our data also highlight the critical need to preserve and restore Riparian Montezuma Cypress-Sabal Woodlands in the LRGV, which not only harbor diverse land snail assemblages, but currently lack restored analogs. Finally, we see a strong influence of some aspects of plant community composition on snail communities in Tamaulipan thorn forest, although further study will be required to tease out the primary drivers.

This work would not be possible without Dr. J. C. Nekola. In addition, we would like to thank F. Dirrigl, Jr., B. Christoffersen, C. Vitek, E. Ruiz, A. Morrison, D. Salinas, and M. Martinez Cruz for their help with field surveying, laboratory work, and data analysis. This research was funded by Texas Parks and Wildlife Department (State Wildlife Grant 2016-18), the University of Texas Rio Grande Valley College of Sciences, and the University of Texas Rio Grande Valley College of Sciences High Scholars Program.

\section{Literature Cited}

Abdel-Rehim, A. H. 1983. The effects of temperature and humidity on the nocturnal activity of different shell colour morphs of the land snail Arianta arbustorum. Biological Journal of the Linnean Society 20:385-395.

Almeida-Neto, M., P. Guimarães, P. R. Guimarães, R. D. Loyola, AND W. UlRICH. 2008. A consistent metric for nestedness analysis in ecological systems: reconciling concept and measurement. Oikos 117:1227-1239.

Bartlett, J. R. 1856. Personal narrative of explorations and incidents in Texas, New Mexico, California, Sonora, and Chihuahua: connected with the United States and Mexican Boundary Commission, during the years 1850, '51, '52, and '53. D. Appleton and Company and G. Routledge and Company, New York.

BAUR, B., AND A. BAur. 1993. Climatic warming due to thermal radiation from an urban area as possible cause for the local extinction of a land snail. Journal of Applied Ecology 30:333340.

BLAIR, W. F. 1950. The biotic provinces of Texas. Texas Journal of Science 2:93-117.

Brush, T. 2005. Nesting birds of a tropical frontier: the lower Rio Grande Valley of Texas. Texas A\&M University Press, Kingsville.

Brush, T., and M. H. Conway. 2016. Subspecific and breeding status of the common yellowthroat (Geothlypis trichas) at Santa Ana National Wildlife Refuge, Hidalgo County, Texas. The Southwestern Naturalist 61:321-324.

ByERs, J. E. 2002. Impact of non-indigenous species on natives enhanced by anthropogenic alteration of selection regimes. Oikos 97:449-458.

Caldwell, R. S. 1993. Macroinvertebrates and their relationship to coarse woody debris: with special reference to land snails. United States Department of Agriculture Forest Service SE94:49-54.

Cameron, R. A. D., and B. M. Pokryszko. 2005. Estimating the species richness and composition of land mollusc communities: problems, consequences and practical advice. Journal of Conchology 38:529-547.

Clover, E. U. 1937. Vegetational survey of the lower Rio Grande Valley, Texas. Madro 4:77-100.

Cook, T., J. Adams, A. Valero, J. Schipper, and T. Allnutt. 2000. Southern North America: Southern United States into northeastern Mexico. Available at: https://www. worldwildlife.org/ecoregions/na1312.

Cortez, I., C. J. Vitek, M. W. Persans, and K. L. Lowe. 2017. Seasonal detection of atrazine and atzA in man-made waterways receiving agricultural runoff in a subtropical, semi-arid environment (Hidalgo County, Texas, USA). World Journal of Microbiology and Biotechnology 33:38.

Danielsen, F., H. Beukema, N. D. Burgess, F. Parish, C. A. Bruhl, P. F. Donald, D. Murdiyarso, B. Phalan, L. Reijnders, M. Struebig, and E. B. Fitzherbert. 2009. Biofuel plantations on forested lands: double jeopardy for biodiversity and climate. Conservation Biology 23:348-358. 
DAvies, P. 2008. Snails: archaeology and landscape change. Oxbow Books, Limited, Havertown, Pennsylvania.

DirRigl, F. J. 2012. Effectiveness of pan trapping as a rapid bioinventory method of freshwater shoreline insects of subtropical Texas. Southwestern Entomologist 37:133-139.

Douglas, D. D., D. R. Brown, and N. Pederson. 2013. Land snail diversity can reflect degrees of anthropogenic disturbance. Ecosphere 4:1-14.

Dvořáková, J., AND M. Horsák. 2012. Variation of snail assemblages in hay meadows: disentangling the predictive power of abiotic environment and vegetation. Malacologia 55:151-162.

EdDY, M. R., AND F. W. JudD. 2004. Comparison of branch elongation among four Acacia species and Texas ebony in the Lower Rio Grande Valley of Texas. The Texas Journal of Science 56:253-262.

Elliott, L. F., D. D. Diamond, D. C. True, C. F. Blodgett, D. Pursell, D. German, and A. Treuer-Kuehn. 2014. Ecological mapping systems of Texas: Summary Report. Texas Parks and Wildlife Department, Austin. Available at: https:// tpwd.texas.gov/gis / programs/landscape-ecology/ supporting-documents/final-summary-report.

Emberton, K. C., T. A. Pearce, P. F. Kasigwa, P. Tattersfield, and Z. HABIBU. 1997. High diversity and regional endemism in land snails of eastern Tanzania. Biodiversity and Conservation 6:1123-1136.

George, W. E. 2008. Lost Architecture of the Rio Grande Borderlands: 7. Texas A\&M University Press, College Station.

Getz, L., AND G. Uetz. 1994. Species diversity of terrestrial snails in the southern Appalachian Mountains, USA. Malacological Review 27:61-74.

Haines, A. M., J. E. Janecka, M. E. Tewes, L. I. Grassman, JR., and P. MorTon. 2006. The importance of private lands for ocelot Leopardus pardalis conservation in the United States. Oryx 40:90-94.

HAusdorf, B. 2018. Beyond Wallace's line-dispersal of Oriental and Australo-Papuan land-snails across the Indo-Australian Archipelago. Zoological Journal of the Linnean Society 185:66-76.

Hausdorf, B., and C. Hennig. 2003. Nestedness of north-west European land snail ranges as a consequence of differential immigration from Pleistocene glacial refuges. Oecologia 135:102-109.

Heino, J., H. Mykrä, And J. Rintala. 2010. Assessing patterns of nestedness in stream insect assemblages along environmental gradients. Ecoscience 17:345-355.

Hettenbergerová, E., M. Horsák, R. Chandran, M. Hájek, D. Zelený, and J. Dvořáková. 2013. Patterns of land snail assemblages along a fine-scale moisture gradient. Malacologia 56:31-42.

Hijmans, R., M. Cruz, E. Rojas, and L. Guarino. 2001. DIVA-GIS version 1.4: a geographic information system for the analysis of biodiversity data. Manual. International Potato Center, Lima, Peru.

Hijmans, R., S. Cameron, J. Parra, P. Jones, A. Jarvis, and K. RichARDSON. 2005. WorldClim, version 1.3. University of California, Berkeley. International Potato Center, Lima, Peru.

Hoffmann, M. H., S. Meng, P. A. Kosachev, T. A. Terechina, and M. M. Silanteva. 2011. Land snail faunas along an environmental gradient in the Altai Mountains (Russia). Journal of Molluscan Studies 77:76-86.

Horáčková, J., L. JuřičKová, A. L. Šizling, V. Jarošík, and P. Pyšek. 2014. Invasiveness does not predict impact: response of native land snail communities to plant invasions in riparian habitats. PLoS ONE 9:e108296.

Horsák, M., L. JuŘičKovÁ, K. Kintrová, And O. HáJEk. 2009a. Patterns of land snail diversity over a gradient of habitat degradation: a comparison of three Czech cities. Biodiversity and Conservation 18:3453-3466.

Horsák, M., M. Chytrý, J. Danihelka, M. Kočí, S. Kubešová, Z. Lososová, Z. ОтÝPKOva, AND L. TICHÝ. 2009b. Snail faunas in the Southern Ural forests and their relations to vegetation: an analogue of the Early Holocene assemblages of Central Europe? Journal of Molluscan Studies 76:1-10.

Ноторт, K. P. 2002. Land snails and soil calcium in central Appalachian Mountain forest. Southeastern Naturalist 1:2744.

Hylander, K., G. Nilsson, And T. Gothner. 2004. Effects of bufferstrip retention and clearcutting on land snails in boreal riparian forests. Conservation Biology 18:1052-1062.

IDEKER, J. 1979. The associated gastropod fauna of the Santa Ana National Wildlife Refuge with notes on a colony of the snail, Helicina orbiculata. The Southwestern Naturalist 24:687-689.

Jahrsdoerfer, S. E., And D. M. Leslie, JR. 1988. Tamaulipan brushland of the lower Rio Grande Valley of south Texas: description, human impacts, and management options. Oklahoma Cooperative Fish and Wildlife Research Unit Stillwater 88(36).

Kappes, H., W. Topp, P. Zach, And J. Kulfan. 2006. Coarse woody debris, soil properties and snails (Mollusca: Gastropoda) in European primeval forests of different environmental conditions. European Journal of Soil Biology 42:139-146.

Kappes, H., M. Jabin, J. Kulfan, P. Zach, and W. Topp. 2009. Spatial patterns of litter-dwelling taxa in relation to the amounts of coarse woody debris in European temperate deciduous forests. Forest Ecology and Management 257:1255-1260.

LAKE, P. S., AND D. J. O'Dowd. 1991. Red crabs in rain forest, Christmas Island: biotic resistance to invasion by an exotic snail. Oikos 25-29.

LANGE, C. N. 2003. Environmental factors influencing land snail diversity patterns in Arabuko Sokoke forest, Kenya. African Journal of Ecology 41:352-355.

LESLIE, D. M., JR. 2016. An international borderland of concern: conservation of biodiversity in the lower Rio Grande Valley. United States Geological Survey, Reston, Virginia.

Lockett, L., AND R. W. READ. 1990. Extension of native range of Sabal mexicana (Palmae) in Texas to in central coast. SIDA, Contributions to Botany 14:79-85.

LONARD, R. I., AND F. W. JUDD. 2002. Riparian vegetation of the lower Rio Grande. The Southwestern Naturalist 47:420-432.

Lososová, Z., M. Horsák, M. Chytrý, T. Čejka, J. Danihelka, K. Fajmon, O. Hájek, L. JuřičKová, K. Kintrová, D. Láníková, Z. OTÝpková, V. ŘEHoŘEK, AND L. TichÝ. 2011. Diversity of Central European urban biota: effects of human-made habitat types on plants and land snails. Journal of Biogeography 38:11521163.

Luniak, M. 2008. Fauna of the big city-estimating species richness and abundance in Warsaw Poland. Pages 349-354 in Urban ecology: an international perspective on the interaction between humans and nature (J. M. Marzluff, E. Shulenberger, W. Endlicher, M. Alberti, G. Bradley, C. Ryan, U. Simon, and C. ZumBrunnen, editors). Springer, Boston, Massachusetts.

Mandujano, M. C., A. Flores-Martínez, J. Golubov, and E. EzcurRa. 2002. Spatial distribution of three globose cacti in 
relation to different nurse-plant canopies and bare areas. The Southwestern Naturalist 47:162-168.

Maraun, M., H. Martens, S. Migge, A. Theenhaus, and S. Scheu. 2003. Adding to 'the enigma of soil animal diversity': fungal feeders and saprophagous soil invertebrates prefer similar food substrates. European Journal of Soil Biology 39:85-95.

McMillan, M. A., J. C. Nekola, and D. W. Larson. 2003. Effects of rock climbing on the land snail community of the Niagara Escarpment in southern Ontario, Canada. Conservation Biology 17:616-621.

Müller, J., C. STRÄtz, and T. Hothorn. 2005. Habitat factors for land snails in European beech forests with a special focus on coarse woody debris. European Journal of Forest Research 124:233-242.

NekolA, J. 2002. Effects of fire management on the richness and abundance of central North American grassland land snail faunas. Animal Biodiversity and Conservation 25:53-66.

Nekola, J. C. 2014. Overview of the North American terrestrial gastropod fauna. American Malacological Bulletin 32:225235.

Nilsson, S. G., J. Bengtsson, And S. As. 1988. Habitat diversity or area per se? Species richness of woody plants, carabid beetles and land snails on islands. The Journal of Animal Ecology 685-704.

Perez, K. E., E. Ruiz, M. Martinez Cruz, and R. L. Minton. 2017. A new species of South Texas scrubsnail, Praticolella (von Martens, 1892) (Gastropoda: Polygyridae). Nautilus 131:6775.

Peters, E. M., C. Martorell, and E. Ezcurra. 2008. Nurse rocks are more important than nurse plants in determining the distribution and establishment of globose cacti (Mammillaria) in the Tehuacán Valley, Mexico. Journal of Arid Environments 72:593-601.

Rankevich, D., B. Lavie, E. Nevo, A. Beiles, and Z. Arad. 1996. Genetic and physiological adaptations of the prosobranch landsnail Pomatias olivieri to microclimatic stresses on Mount Carmel, Israel. Israel Journal of Zoology 42:425-441.

R Core TeAm. 2013. R 3.4.2: a language and environment for statistical computing. R Foundation for Statistical Computing, Vienna, Austria. Available at: http://www.r-project.org/.

Richardson, A. M. M. 1975. Food, feeding rates and assimilation in the land snail Cepaea nemoralis L. Oecologia 19:59-70.

Robinson, D. G. 1999. Alien invasions: the effects of the global economy on non-marine gastropod introductions into the United States. Malacologia 41:413-438.

Rosin, Z. M., A. Lesicki, Z. Kwieciński, P. SkóRka, And P. TRYJANOWSKI. 2017. Land snails benefit from human alterations in rural landscapes and habitats. Ecosphere 8:e01874.

Roxburgh, S. H., K. Shea, and J. B. Wilson. 2004. The Intermediate Disturbance Hypothesis: patch dynamics and mechanisms of species coexistence. Ecology 85:359-371.

Schilthuizen, M., AND H. A. Rutjes. 2001. Land snail diversity in a square kilometre of tropical rainforest in Sabah, Malaysian Borneo. Journal of Molluscan Studies 67:417-423.

Schilthuizen, M., T.-S. Liew, B. B. Elahan, and I. LackmanANCRENAZ. 2005. Effects of karst forest degradation on pulmonate and prosobranch land snail communities in Sabah, Malaysian Borneo. Conservation Biology 19:949-954.

SEVERns, P. M. 2005. Response of a terrestrial mollusc community to an autumn prescribed burn in a rare wetland prairie of western Oregon, USA. Journal of Molluscan Studies 71:181187.

SFA Gardens. 2002. Pineywoods Native Plant Center, Spring 2002. SFA Gardens Newsletters 56. Stephen F. Austin State University, Nacogdoches, Texas. Available at: https:// scholarworks.sfasu.edu/sfa_gardens_newsletters/56.

Shreve, F. 1910. The rate of establishment of the giant cactus. The Plant World 13:235-240.

Staikou, A. E. 1999. Shell temperature, activity and resistance to desiccation in the polymorphic land snail Cepaea vindobonensis. Journal of Molluscan Studies 65:171-184.

Steensma, K. M. M., P. L. Lilley, ANd H. M. Zandberg. 2009. Life history and habitat requirements of the Oregon forestsnail, Allogona townsendiana (Mollusca, Gastropoda, Pulmonata, Polygyridae), in a British Columbia population. Invertebrate Biology 128:232-242.

Suzán-Azpiri, H., G. Enríquez-Peña, and G. Malda-Barrera. 2007. Population structure of the Mexican baldcypress (Taxodium mucronatum Ten.) in Queretaro, Mexico. Forest Ecology and Management 242:243-249.

Tremblay, T. A., W. A. White, and J. A. Raney. 2005. Native woodland loss during the mid-1900s in Cameron County, Texas. The Southwestern Naturalist 50:479-482.

VAn den Brink, P. J., AND C. J. F. Ter BraAk. 1998. Multivariate analysis of stress in experimental ecosystems by principal response curves and similarity analysis. Aquatic Ecology 32:163-178.

Vitek, C. J., J. A. Gutierrez, and J. F. J. Dirrigl. 2014. Dengue vectors, human activity, and dengue virus transmission potential in the lower Rio Grande Valley, Texas, United States. Journal of Medical Entomology 51:1019-1028.

Watters, G. T., T. Menker, and S. H. O’Dee. 2005. A comparison of terrestrial snail faunas between strip-mined land and relatively undisturbed land in Ohio, USA-an evaluation of recovery potential and changing faunal assemblages. Biological Conservation 126:166-174.

Zellweger, F., V. Braunisch, F. Morsdorf, A. Baltensweiler, M. Abegg, T. Roth, H. Bugmann, and K. Bollmann. 2015. Disentangling the effects of climate, topography, soil and vegetation on stand-scale species richness in temperate forests. Forest Ecology and Management 349:36-44.

Submitted 4 April 2019. Accepted 27 May 2020.

Associate Editor was Jerry Cook. 